
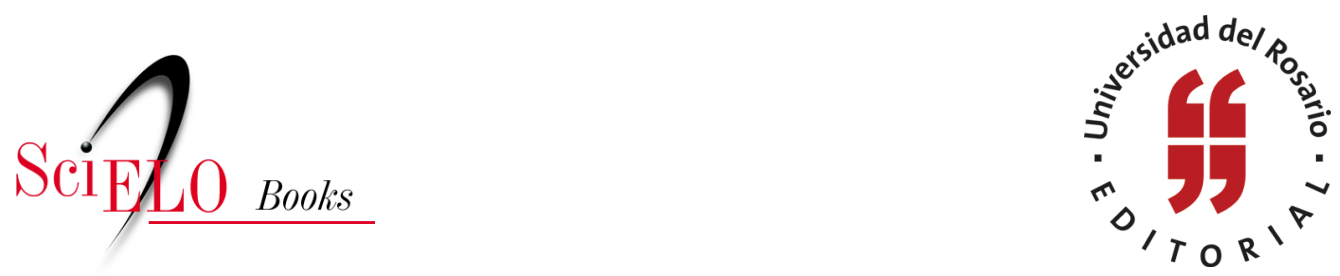

\title{
La función de las imágenes en el proceso de construcción de las naciones latinoamericanas
}

\author{
Hans-Joachim König
}

\section{SciELO Books / SciELO Livros / SciELO Libros}

KÖNIG, H-J. La función de las imágenes en el proceso de construcción de las naciones latinoamericanas. In: SCHUSTER, S., ed. La nación expuesta. Cultura visual y procesos de formación de la nación en América Latina [online]. Bogotá: Editorial Universidad del Rosario, 2014, pp. 1-28. Textos de ciencias humanas collection. ISBN: 978-958-738-524-3. https://doi.org/10.7476/9789587385243.0002.

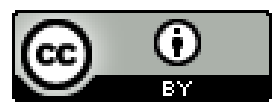

All the contents of this work, except where otherwise noted, is licensed under a Creative Commons Attribution 4.0 International license.

Todo o conteúdo deste trabalho, exceto quando houver ressalva, é publicado sob a licença Creative Commons Atribição 4.0.

Todo el contenido de esta obra, excepto donde se indique lo contrario, está bajo licencia de la licencia Creative Commons Reconocimento 4.0. 


\title{
La función de las imágenes en el proceso de construcción de las naciones latinoamericanas
}

\author{
Hans-Joachim König \\ Katholische Universität Eichstätt-Ingolstadt
}

\section{Símbolos nacionales en la construcción de un Estado nuevo}

En la primera parte de mi ensayo, presento algunas reflexiones teóricas acerca de los símbolos nacionales y la retórica política. Uno de los deberes más importantes de los dirigentes políticos de un Estado nuevo es desarrollar o consolidar en la población un sentimiento de identidad y de identificación con el nuevo Estado y conseguir, a la vez, su reconocimiento por los ciudadanos.

Los problemas de identidad y de legitimidad representan los primeros y más fundamentales desafíos en el proceso de la formación del Estado y de la nación, particularmente en el caso de los Estados hispanoamericanos que se emanciparon de la dependencia colonial, porque su gobierno ya no estaba legitimado por el principio monárquico habitual con la persona del rey como persona de referencia y objeto de lealtad, sino por el nuevo principio de la soberanía popular. Se consideran soluciones institucionales de estos problemas el desarrollo de medios impresos, de organizaciones para la socialización y el fomento de la cultura política, como escuelas, museos, ritos y símbolos, así como la garantía de obedecer las leyes, los reglamentos y cumplir con la responsabilidad gubernamental.

Al estallar la independencia todavía no existían los museos nacionales. Estos, como lugares de la memoria que consolidan una narrativa de la nación o de la comunidad deseada, como partes integrantes del proceso de unificación política del territorio y de la construcción de los Estados nacionales, surgían solo años después de la independencia. Por eso, ya que no existían instituciones que pudieran ates- 
tiguar la esencia del pasado glorioso, la "sede ceremonial del patrimonio, el lugar en el que se guarda y celebra, donde se reproduce el régimen semiótico con que los grupos hegemónicos lo organizaron" (García Canclini 1989, 158), los dirigentes políticos de los Estados latinoamericanos hacían lo que los políticos de todos los tiempos y de todas partes practicaban o todavía están practicando para difundir ideas políticas: crear una conciencia nacional y determinar el portador de la soberanía popular. Se servían para ello de una serie de símbolos y de una retórica política especial, que se manifiesta en ciertas imágenes, tanto virtuales o mentales como reales (véanse Deichmann 2007; Diers 1997; Bergem, Blum y Marx 1996).

Para darnos cuenta del carácter y de la función de las imágenes, podemos basarnos en las teorías de la imagología y los trabajos de la psicología social que investigan ciertos comportamientos y pareceres estereotipados. ${ }^{1}$ Ellos nos suministran suficientes conocimientos para comprender cómo se forman las imágenes, tanto las imágenes de sí mismo (autoimagotype) como las imágenes del ajeno, del otro (heteroimagotype). Son las imágenes que definen la idea de nosotros mismos y las de los otros. De estas imágenes no se puede percibir si sea "correcta" o "incorrecta". De hecho, la conformidad de la imagen con la realidad es, por el momento, de poca importancia. Las imágenes son productos de opiniones particulares -en la política, muchas veces lanzadas por grupos dominantes- y, así, son funciones de situaciones sociales. Las imágenes son medios orientadores imprescindibles que ponen al receptor, sea un individuo, una sociedad o una nación, en condiciones de relacionar las diversas informaciones e impresiones sensoriales, estructurarlas y agregarlas a tipos de interpretación ya existentes (Cfr. Bergler 1966, 108). Una imagen estereotipada sirve de filtro, por así decirlo, para extinguir partes no deseadas de las informaciones nuevas o hasta omitirlas. Con estas imágenes estereotipadas se construye la realidad que manejan tanto individuos como grupos colectivos, y esta realidad construida se convierte en la base de valoraciones, decisiones, acciones y pautas de conducta (comportamientos).

Las metáforas son imágenes muy especiales. Ellas expresan términos figurativos que sirven para la descripción gráfica y suministran ciertas significaciones e interpretaciones. Sus características centrales son, por un lado, su potencial de visualizar y, por el otro, la impresión de una cosa terminante y patente, impresión que muchas veces contrasta con la complejidad real de la cosa indicada.

\footnotetext{
1 Acerca de esta teoría véase Boulding (1956/1969); Bergler (1966); Fischer (1979); Hoffmann (1960); Siebenmann (1992).
} 
Las metáforas crean relaciones conceptuales entre fenómenos, por el momento heterogéneos, por ejemplo, entre el concepto de la familia como lenguaje simbólico y la esfera de lo político como receptor de la imagen. Ilustran así una realidad por el momento opaca, al interpretar algo abstracto por un símbolo concreto y comprimirlo en figuras lingüísticas. Por eso, las metáforas no representan una realidad, sino que la producen. Según Paul Ricœur $(1986,275)$, producen una referencia virtual y así crean una realidad que pretenden describir. De este modo, las metáforas en su calidad de lenguaje simbólico son ofertas para interpretar situaciones o realidades políticas muy complejas y ofrecer explicaciones simples y fáciles de comprender, lo que argumentaciones discursivas apenas lograrían suministrar (véanse al respecto Ricœur 1986; Davidson 1986; Haverkamp 1983). Hay que subrayar que el efecto de metáforas y de símbolos está basado en que estos tocan una predisposición en aquellos individuos o grupos a que se dirigen, a la cual pueden referir y gracias a la cual son reconocidos. Este hecho induce a comprender que imágenes, metáforas, símbolos y su contenido no son constantes o invariables, sino que se modifican en la medida que las condiciones históricas cambian (Cfr. Deutsch 1953, 170-181; Walzer 1967, 191-204).

Antes de analizar la retórica política en la época de la independencia, me parece necesario dar algunas explicaciones teóricas respecto al concepto de nación, que parece escaparse de una definición generalmente aceptada. No me baso en una definición de nación que la determina como un orden natural y terminante de la vida política y social, pues ya se sabe y se ha descrito muchas veces lo difícil que es encontrar un código universal para lo que es una nación en general y en una situación especial. En cambio, prefiero aplicar un concepto que comprende la nación como un orden ficticio, determinado por una colectividad de hombres, donde la naturaleza de este conjunto se deduce de los criterios o cualidades diferentes, como los definen en la mayoría de los casos las élites dominantes. Estos criterios determinantes que sirven para diferenciar hacen aparecer, al mismo tiempo, lo diferenciado como un valor especial (aspecto normativo) y de este modo proporcionan una orientación. Pueden ser, por ejemplo, criterios étnicos, criterios culturales o criterios de derechos humanos cívicos. Según las diferentes cualidades que obtengan mayor valor en un orden ficticio de la nación, se forman naciones diferentes, que están sujetas a cambios cada vez que los criterios determinantes y su valor o una 
mezcla de criterios, cambien en el transcurso de los tiempos y que son adaptables a las constelaciones reales de poder en el proceso histórico. ${ }^{2}$

Este concepto analítico ofrece la ventaja de que pregunta por y hace comprensible lo que los contemporáneos (sobre todo los personajes dominantes de una sociedad) entienden por la nación en una determinada situación histórica, cuáles son los criterios con los que definen la nación de un modo igualmente plausible para las no élites y cómo legitiman el orden político o justifican la fundación y construcción del Estado. De este modo, se evita confundir el concepto de la nación que tuvieron los contemporáneos con aquel del historiador, quien en una retrospectiva histórica trata de calificar la existencia de la nación estudiando si se encuentra una cantidad mínima de integración nacional en el sentido social, económico y también geográfico.

Desde este aspecto teórico, la cuestión primordial no sería si ya en el momento de la independencia existía una nación, comparada con categorías "objetivas", universales o tomadas de la historia europea de Estados nacionales. Me parece de mayor importancia estudiar cómo los criollos entendieron la nación y con qué proyecto nacional la construyeron, siendo ellos los predominantes, si bien no los únicos, representantes del movimiento nacional que, compitiendo con otros proyectos nacionales, lograron imponer su propia versión (véanse König 1994 y 2000; Múnera 1998).

Como podemos partir del supuesto de que existen relaciones muy estrechas entre el lenguaje, la política y el gobierno, las metáforas, las imágenes mentales y reales son más que figuras de dicción meramente decorativas, y su análisis es de una importancia trascendental (Cfr. Lasswell 1949; Weldon 1953; Dieckmann 1964; Pocock 1971; Zashin y Chapman 1974; Cohen 1979; Ortony 1979; Sapir y Crocker 1977; Miller 1979).

\section{Algunos ejemplos respecto de imágenes}

En la segunda parte de mi ensayo, analizo la función de algunas imágenes en la primera fase de la construcción de las naciones latinoamericanas. Me refiero al caso de la Nueva Granada/Colombia, porque lo he estudiado intensamente. Enseguida me enfoco en el significado de algunos símbolos, porque me parece que este análisis

2 He analizado en varios trabajos tanto la problemática de definición como la posibilidad de aplicar un concepto de nación como orden ficticio o un concepto de proyecto nacional (König 1994, 2000 y 2003). 
facilita precisar exposiciones sobre la interpretación de la realidad y la orientación de conductas relacionadas con la formación de la nación, así como sobre las bases de la legitimación del nuevo gobierno. También, dicho análisis permite enterarse de los modos de pensar y sentir incluso de grupos mayores. Respecto de los modos de pensar, el lenguaje representa el depósito de esquemas específicos de cada época y sociedad, de expectativas y actitudes, es decir, el "saber social" expresado en determinadas nociones (véanse Schütz y Luckmann 1979; Berger y Luckmann 1966; Gumprecht 1979). Sobre todo, voy a analizar el lenguaje de la élite neogranadina; los criollos dominantes, siendo ellos los representantes del movimiento nacional y los que, desde finales del siglo XVIII, llegaron a tener, una cada vez mayor, conciencia de su identidad y un creciente sentido de lealtad con su patria.

Dentro de la retórica política con que los patriotas, como portadores del movimiento de independencia, se enfrentaron al poder colonial español a través de escritos políticos, artículos de periódicos junto con cartas particulares y oficiales, así como en las primeras constituciones, fueron de importancia las siguientes metáforas y eslóganes: el imperio español visto como familia, la relación entre España y sus colonias concebida como relación entre padre/madre e hijos, la fórmula de trescientos años de esclavitud de los americanos, el indio como símbolo de la esclavitud o bien de la libertad, según el caso, el árbol de la libertad y el título de ciudadano. Aquí me dedicaré a los tres primeros. ¿Qué contenido y función tuvieron estos símbolos políticos en la Nueva Granada durante la época de la primera organización estatal?

\section{La metáfora de la familia}

"El Nuevo Reino de Granada es hoy como un hijo mayor que necesita emanciparse": con este argumento justificó Pedro Fermín de Vargas en 1799 las aspiraciones independentistas neogranadinas (citado en Ortiz 1965, 71). Vargas fue un buen conocedor del país, debido a su actividad como funcionario en la Secretaría del virrey Caballero y Góngora y como corregidor de Zipaquirá. Doce años más tarde, el prócer Antonio Nariño, presidente del Estado de Cundinamarca, criticó a España usando una imagen similar. En una carta divulgada el $1^{\circ}$ de septiembre de 1811 del número 8 de La Bagatela, su diario de combate político y estilo satírico, preguntaba con qué derecho se designaba propiamente a España como $\mathrm{Madre} \mathrm{Pa}$ tria, cuando esta se había mostrado como Madrasta Patria codiciosa y dominante, en vez de una madre cuidadosa: 
Si ella tiene alguna similitud con la natural, no viene de que las Américas se hayan portado como hijas: era necesario que la España hubiese hecho oficios de madre, así como merecer el título de Patria; creo yo que la España debiera de haber sido para los Americanos, lo que América ha sido para los españoles. Estos, que tanto cacarean de la maternidad, pudieran señalarnos el patriotismo que heredamos de aquella madre, entre tanto que la tal madre, después de haberse mantenido á expensas de la hija, no exige su filiación sino en quanto pretende sobrevivir á ella y heredarla [...].

Mil veces he deseado saber quien sea la Abuela Patria, la Hermana Patria, la Prima Patria, la Tía Patria, sin que de todas mis inquisiciones haya sacado otro conocimiento que el de la Madrastra Patria, aquella que ha tratado siempre como extraños a sus descendientes, y a sus hijos como esclavos. Tengo esta maternidad pegadisa por una Bagatela; pero bagatela que influye mucho en la emancipación de unos pueblos que se forman por sí mismos, y de donde es preciso desterrar el lenguaje de la dependencia. (Nariño 1966, 32)

De modo significativo fue firmada esta carta que evaluaba la conducta de España, al compararla con la de una madrastra con el seudónimo de "Entenado". Con sus declaraciones, Fermín de Vargas y Antonio Nariño aplicaban un concepto bien conocido del pensamiento político español y europeo, pues la analogía entre familia y autoridad política, entre dominación y patria potestad, era una metáfora conocida tanto en la Antigüedad como en la Edad Media. Teóricos del Estado como Platón, Aristóteles, Tomás de Aquino y Marsilio de Padua la propagaron. Filósofos como Jean Bodin y Johannes Althusius acentuaban la autoridad paterna y ampliaban el significado de la metáfora de la familia que desde el siglo XVII sirvió como justificación directa para la pretensión de los monarcas de reclamar la obediencia política. En Inglaterra, Robert Filmer era un notable representante de esta teoría patriarcal que confirmaba la relación entre el derecho divino y el poder. En contraposición a él, John Locke, como partidario de la teoría del contrato social, había deducido de la figura de la familia el derecho a la protección paterna como el argumento de la potestad paterna, es decir, la dominación temporal limitada por causa de la maduración de los hijos (Schochet 1975).

Por consiguiente, la metáfora de la familia podía ser interpretada y empleada según los respectivos intereses. Transferida a la situación de un imperio colonial, bien podía expresar de una manera asimilable las relaciones entre la metrópoli y sus colonias. Así, ya había prestado argumentación a los separatistas en las luchas 
emancipadoras de las colonias inglesas en América. Esta imagen de la maduración y la patria potestad limitada, también fue argüida por Thomas Payne, quien con sus escritos Common Sense y American Crisis ejerció una influencia esencial en el movimiento independentista norteamericano. Sus escritos no eran desconocidos en Sudamérica (véase Burrows y Wallace 1972). Con ello, la efectividad de la metáfora también quedó indirectamente a la vista de los criollos.

Los teóricos del Estado y simpatizantes de la política del absolutismo ilustrado de los Borbones también se servían de esta metáfora. Tal política estaba encaminada a establecer, con medidas políticas, fiscales y administrativas, un moderno Estado nacional unitario. Por consiguiente, fortalecía la autoridad central y realzaba la figura del rey como representante de un Estado que debía verse como instrumento dinámico de un cambio socioeconómico procedente de arriba, que lo declarara administrador del bien común y, en suma, pretendiese una objetivación de las relaciones entre la Corona y los súbditos hasta entonces de carácter personal.

Por ende, la metáfora de la familia — referida a la autoridad paterna del rey y a la autoridad imperial de la Madre Patria en relación con las colonias— también suministraba a los criollos un instrumento adecuado para expresar sus reivindicaciones, tanto respecto de la participación política y económica como de una creciente autonomía. Al mismo tiempo servía para criticar la política española sin ser o parecer desleales, y de este modo, desde un principio, dar escarmiento a los criollos que permanecían fieles a la Corona, si bien de manera vacilante. La idea de que cabía comparar las relaciones imperiales con aquellas entre padres e hijos ofrecía a los criollos la posibilidad de justificar asimismo sus actividades políticas con el derecho natural. Aplicaron en su argumentación ambos aspectos - la minoría de edad no significaría servidumbre y estaría temporalmente delimitada-. A finales del siglo XViII y a comienzos del siglo XIX, en la mayoría de los casos, los criollos utilizaron la metáfora de la familia en forma de cauteloso reclamo, por el cumplimiento de los derechos y las obligaciones recíprocas de padres e hijos. Así, por ejemplo, el memorial elevado al rey español en el proceso de 1794-1795 reclamaba la "paternal piedad", el auxilio paterno para "una hija en la presencia de su buen Padre" y los demandantes sentían su esperanza en el "paternal influxo". El 5 de enero de 1808, el corregidor de Pamplona, Joaquín Camacho, futuro prócer, elevó un memorial al rey español con la pretensión de recibir otro empleo en vista de su próximo traslado: "El amor paternal de vuestra majestad se derrama igualmente sobre todos sus vasallos [...] y los habitantes de sus remotos dominios de América experimentamos las bondades de vuestra majestad como lo experimentan los 
moradores del Ebro y del Tajo. Vuestra majestad es el padre común a quien debemos todos nuestra felicidad" (Martínez Delgado 1954, 360).

Pero las circunstancias externas cambiaban en favor de los criollos: la ocupación de España por los franceses, el derrocamiento de los Borbones y la política de gobiernos provisionales como la Junta Suprema en Sevilla y el Consejo de Regencia permitieron a los criollos exigir más autonomía política para las colonias. Cuando la penosa situación que vivía España puso al descubierto que la relación de dependencia se había invertido y la Madre Patria necesitaba el auxilio de las colonias, y cuando, luego del retorno de Fernando VII al trono, España trataba de reconquistar por la fuerza a los Estados soberanos, ahora los criollos se sirvieron de la metáfora con toda franqueza y con todo rigor.

Especialmente en la imagen de la Madrastra, contrapuesta a la imagen de la Madre Patria, los criollos podían resumir con tono emocional toda la crítica al sistema colonial español, tal como había sido formulada desde finales del siglo XviII. Así, la Proclamación de la Junta de Gobierno de las Provincias Unidas a los Neogranadinos el 6 de octubre de 1814 dijo:

Pero no lo creáis, un padre jamás hace la guerra a sus hijos, y estad seguros de que el gobierno que se constituye en la península, sea cual fuere, no cuidará sino de hacer su felicidad a costa de la vuestra. Trabas y restricciones al comercio para continuar el monopolio que han ejercido en todos vuestros puertos, prohibición de todo género de industrias para manteneros en una eterna infancia; exclusión de extranjeros para cerrar todo camino a la ilustración. (Posada 1924, 92)

La imagen de la Madrastra España, cuyo mal comportamiento llevaba a la interpretación de que deliberadamente mantenía a sus hijos en la minoría de edad, confundiendo infancia con servidumbre e impidiendo el desarrollo que les correspondía, resultaba bastante apropiada para provocar repudio, odio y deseos de resistencia contra el antiguo poder colonial. Esta metáfora sirvió también a próceres de otros Estados como a los chilenos (Cfr. Collier 1967, passim; Lowenthal Felstiner 1983), a los mexicanos (Cfr. Miranda 1952) e incluso a Simón Bolívar, para despertar la conciencia de los americanos acerca del dominio extranjero de los españoles y su política que obstaculizaba el desarrollo. En numerosas cartas, alocuciones públicas y artículos, Bolívar insistió continuamente en que había que reaccionar ante la mayoría de edad y la dependencia, por ejemplo, en la famosa Carta 
de Jamaica de 1815 o en el Discurso de Angostura de 1819 (citado en Presidencia de la República 1962, 149-172 y 210-240).

Si la función de estas imágenes, así como la de otros símbolos y otras fórmulas, era suscitar emociones en contra de España para establecer una delimitación frente a ella, fue entonces la segunda implicación de la metáfora de la familia, es decir, el desarrollo natural y la emancipación de los hijos, la que resultaba de mayor importancia para las circunstancias internas de la Nueva Granada. La fórmula del hijo mayor, del hijo emancipado podía y debía reducir la conciencia colonial, es decir, ayudar a superar el sentimiento de inferioridad, el cual se expresaba en el reconocimiento de la imagen de la Madre Patria, para además, estimular y reforzar la conciencia de la población del Estado establecido o bien en proceso de formación. Numerosos pasajes en alocuciones, proclamas, memorias y artículos de prensa constatan esta asignación de funciones.

Algunas declaraciones de Camilo Torres, el primer presidente de las Provincias Unidas de la Nueva Granada, aclaran cuán importante y convincente resultaba para los dirigentes políticos de la Nueva Granada el argumento de haberse vuelto adultos, y cuán convencidos eran ellos mismos de su validez. El 9 de mayo de 1814, cuando conoció la exhortación del presidente de la Audiencia de Quito, Toribio Montes, leal a la Corona, que la Nueva Granada se rindiera y se subordinara nuevamente a España, Camilo Torres reaccionó en contra de dicho llamado justificando al mismo tiempo la separación de la Nueva Granada de España. Ante todo, defiende Torres el postulado de que la Nueva Granada y América habían llegado a ser adultas, cuando aduce que la separación de esta y de la Nueva Granada, se hubiera presentado aun en el supuesto de un mejor tratamiento por parte de España, porque la emancipación de los hijos/las colonias estaba en el orden de la naturaleza:

Pero sea esto lo que fuere, la América no es libre, porque el gobierno español sea cruel; lo sería y lo debe ser del mismo modo si fuese humano y compasivo. [...] Persuádese a un hombre vigoroso, sano y robusto, que debe estar siempre en un eterno pupilaje, dígale a un hombre de razón, que otro debe administrarle y disponer de sus intereses para que él sea feliz. Hasta la misma naturaleza reprueba este sistema: el hombre a cierta edad no debe reconocer los vínculos paternos que lo ligaron en su infancia, aun los brutos animales tienen esta libertad. Resérvense en hora buena para con los autores de nuestro ser todos los sentimientos que inspiran la gratitud, la naturaleza y la religión. Tengamos, si se quiere, con España, a pesar de sus violencias y crueldades, las consideraciones de 
una aya que por su interes y bien pagada, tal vez nos cuidó, pero su maternidad adoptiva y violenta ha cesado yá; este es el orden de la naturaleza y la razón. (Posada 1927, 302 y ss.)

Al hablar del proceso de separación, Camilo Torres aludió a la desintegración gradual del imperio colonial español, empleando la metáfora de la familia para referirse a los hijos mayores con iguales derechos viviendo uno al lado del otro. No obstante, siguió firme en su convicción de que la Nueva Granada había madurado y que ella misma debía gobernarse. En una carta privada de mayo de 1810, Torres respondió con detalle a la propuesta de su tío Ignacio Tenorio, oidor en la Audiencia de Quito, de que las provincias americanas deberían elegir un gobierno, un Consejo de Regencia en representación a Fernando VII, y expuso sus ideas acerca de las relaciones de la Nueva Granada con España y los demás reinos y provincias americanas comparando el proceso de separación de España con el desarrollo de hijos mayores:

Disuelta la Monarquía y perdida la España, nos hallamos en el mismo caso en que estarían los hijos mayores después de la muerte del padre común. Cada hijo entra en el goce de sus derechos, pone su casa aparte y se gobierna por sí mismo, a no ser que sea menor o fatuo, pues entonces debe sujetarse a la tutela y el dominio de otro. El reino, pues, o provincia de América que por su extensión, su riqueza y población se considerase capaz de formar una gran familia y un Estado independiente, puede y debe hacerlo así, sin buscar un apoyo que no necesita y sin esperar una resolución extraña que nada le importa. (Banco de la República 1960, 66)

Transformaciones importantes en las condiciones de vida colonial llevaron a que ya no se consideraran la inferioridad y la debilidad como las características de las colonias. Antes bien, esta imagen fue sustituida por otra que destacaba el vigor y las posibilidades de desarrollo de los territorios americanos. De manera correspondiente, las personas que se identificaban con esta nueva imagen estuvieron más y más conscientes de sí mismas y comenzaron a rechazar los controles imperiales, como una coerción intolerable a sus propios intereses. Los efectos de tales transformaciones sobre la conciencia general en las colonias se pueden inferir de la transformación simultánea de los símbolos reconocidos hasta entonces. La conversión de la figura de la Madre Patria en la imagen de la Madrastra representaba, en palabras 
de Nariño, en La Bagatela número 8, del $1^{\circ}$ de septiembre de 1811, la superación, el destierro del "lenguaje de la dependencia" (Nariño 1966, 32).

\section{El indio como símbolo de esclavitud o símbolo de libertad}

Tanto en los años inmediatamente anteriores al movimiento independentista como durante este y los primeros del Estado propio, la retórica política de los criollos se caracterizó por la atención prestada a la historia del indio en América y su suerte como conquistado y subyugado. No solamente en la Nueva Granada sino también en otros países como Chile y México, los patriotas aludían al pasado indígena basándose, tanto en la condena de la conquista española y sus repercusiones negativas en la población aborigen como en el rechazo de los títulos de la conquista española. Sabemos que los criollos aprovechaban la historia de la población autóctona para justificar su propia lucha contra el poder colonial español. Lo hicieron con el fin de legitimar sus propias pretensiones de poder e indicar la superación de la esclavitud como meta del movimiento emancipador, pero no con el fin de aplicar valores indígenas en la construcción de los nuevos Estados (véase König 1997).

Así, precisamente la evidente instrumentalización del indio o de lo indiano, nos da a conocer el carácter de una imagen. Mientras que las versiones escritas sobre la historia indígena, considerada "común", se dirigían al reducido estrato de los criollos para hacerles ver cuán justificada era la lucha contra los españoles y moverlos a defender o recuperar sus propios derechos (König 1994, 234-249), la reproducción de imágenes de lo indiano en las monedas o el escudo del país tenía el propósito manifiesto de influir también en los estratos analfabetas de la población para fomentar la solidaridad y crear un sentimiento de identidad en un ámbito más extenso. A la vista de estas monedas, a cualquiera le resultaba evidente cuáles debían ser los rasgos característicos del nuevo Estado y en qué se diferenciaba del antiguo estatus colonial.

Una de las primeras representaciones simbólicas oficiales de lo indiano se dio a conocer en Cartagena de Indias. El 11 de noviembre de 1811, antes que las demás provincias de la Nueva Granada, Cartagena anunció de manera pública y expressis verbis su separación absoluta de España, se declaró Estado soberano e independiente y, para ratificar esta soberanía, consagró sus propios símbolos. Pocos días después de esta declaración de independencia, el 17 de noviembre, el regimiento de Patriotas Pardos prestó juramento a la nueva bandera: blanca y verde, su centro ocupado por un hermoso emblema, combinación de la fruta de la granada en alusión al territorio de la Nueva Granada y tres cangrejos en homenaje al antiguo nombre indígena de 
Cartagena, Calamarí, que significa “cangrejo”. La apelación al pasado, y con esta la intención de dar un sentido al nuevo Estado, se reafirmaba aún más claramente en el nuevo escudo, diseñado junto con una nueva bandera por mandato de la Asamblea Constituyente reunida en enero de 1812 y reproducido en las nuevas monedas de cobre que pronto entraron en circulación. Cada pieza de esta moneda de un diámetro de 26 a 27 milímetros, mostraba, en una de sus caras, la leyenda Estado de Cartagena 1812, con la correspondiente declaración de valor, y en el anverso, el escudo, símbolo de la libertad: una india con una corona de plumas, sentada a la sombra de una palma de coco (figura 1). Esta lleva a la espalda una aljaba con flechas y un arco colgado sobre el hombro, en la mano derecha sostiene una granada, que picotea un pájaro, y en la izquierda, una cadena rota (Barriga Villalba 1969: vol. 2, 128; Gaceta de Colombia 1812).

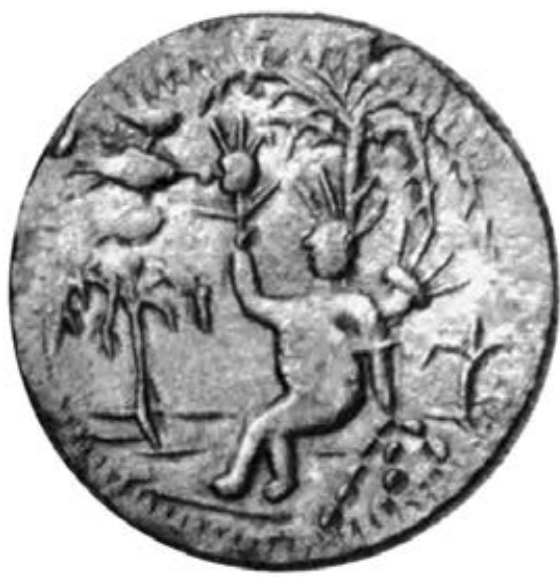

Anverso

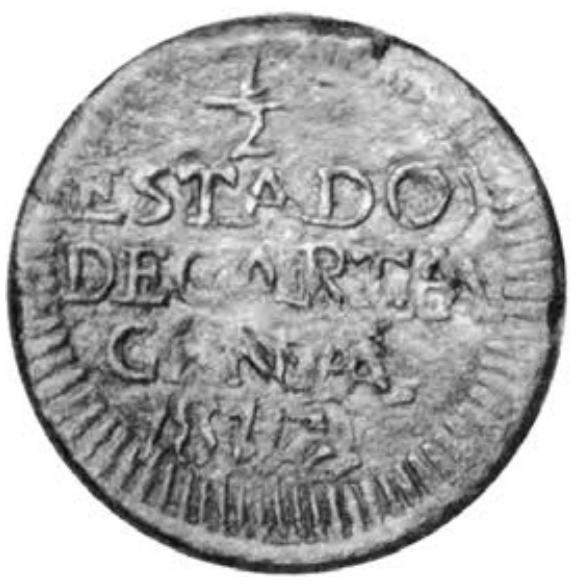

Reverso

Figura 1. Moneda del Estado de Cartagena de 1812

Fuente: Barriga Villalba (1969).

Esta representación simbólica de la libertad en el cuerpo de una amazona americana con armas y corona prestó un nuevo sentido a la figura de la india, que ya había aparecido en cuadros alegóricos del arte europeo como la América personificada. Desde el descubrimiento de un nuevo mundo, en 1492, resurgió la representación alegórica de los continentes por medio de figuras femeninas. Por eso, la india desnuda, muchas veces con armas y signos del canibalismo, tal como la había descrito sobre todo Amerigo Vespucci en su carta Novus Mundus, de 1502 (véase König 1991), se convirtió en el símbolo de América (L’Amérique vue par 
l'Europe 1976; Kohl 1982; Poeschel 1985). En los siglos XVI y XVII, en la imaginación europea, simbolizó tanto una cultura poco civilizada como la subordinación a Europa. Esto se desprende muy bien del grabado en cobre, una alegoría de los cuatro continentes. Se trata de la portada del libro Neuwe Archontologia Cosmica, compilado por Johann Ludwig Gottfried, ilustrado por Matthäus Merian y publicado por primera vez en 1646 (Knefelkamp y König 1988: portada, 222 y 223). A veces América simbolizó también la riqueza del continente, estando representada en la figura de una india con sus frutas, sus animales y sus minerales, es decir, lo que esta parte del mundo ofreció a Europa, subrayando así la importancia que tenían las colonias americanas para el viejo continente. Esto se desprende muy bien de otro grabado en cobre de Matthäus Merian en el libro Historia Antipodum oder Newe Welt (figuras 2 y 3), compilado por Johann Ludwig Gottfried y publicado en 1631 (Knefelkamp y König 1988, 135, 220 y 221).

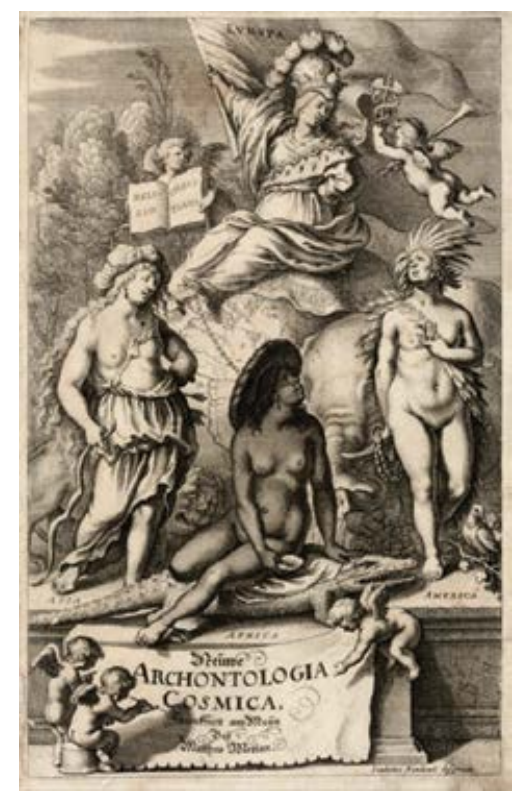

Figura 2. Portada del libro Neuwe Archontologia Cosmica, 1646

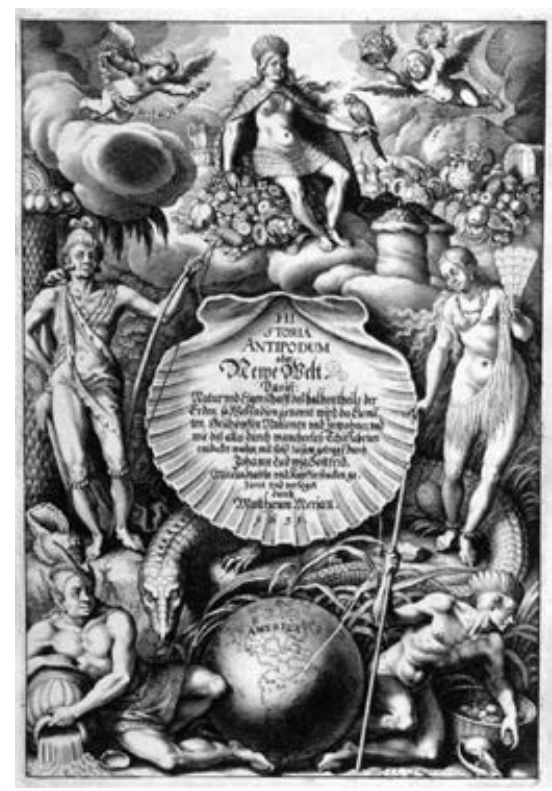

Figura 3. Portada del libro Historia Antipodum oder Newe Welt, 1631

Fuente: Knefelkamp y König (1988).

Fuente: Knefelkamp y König (1988).

Al final del siglo XVIII y al principio del siglo XIX, durante el movimiento de independencia en América del Norte (Cfr. McClung Fleming 1965) y América del Sur, la india americana ahora invocada por los mismos americanos durante el 
movimiento de independencia encarnaba lo propio y lo especial de América frente a Europa (véase Chicangana-Bayona 2010). Culminó esta nueva simbología en el famoso cuadro Simón Bolivar, Libertador i Padre de la Patria de 1819, óleo de Pedro José Figueroa de Bogotá, ahora expuesto en el Museo Quinta de Bolívar en Bogotá (véase Castro, González y González 2004). Este óleo de Bolívar con traje militar abrazando la América India, aunque no tiene tipo indígena, fue una alegoría de la libertad destinada a celebrar los triunfos de Bolívar en la batalla de Boyacá (figura 4).

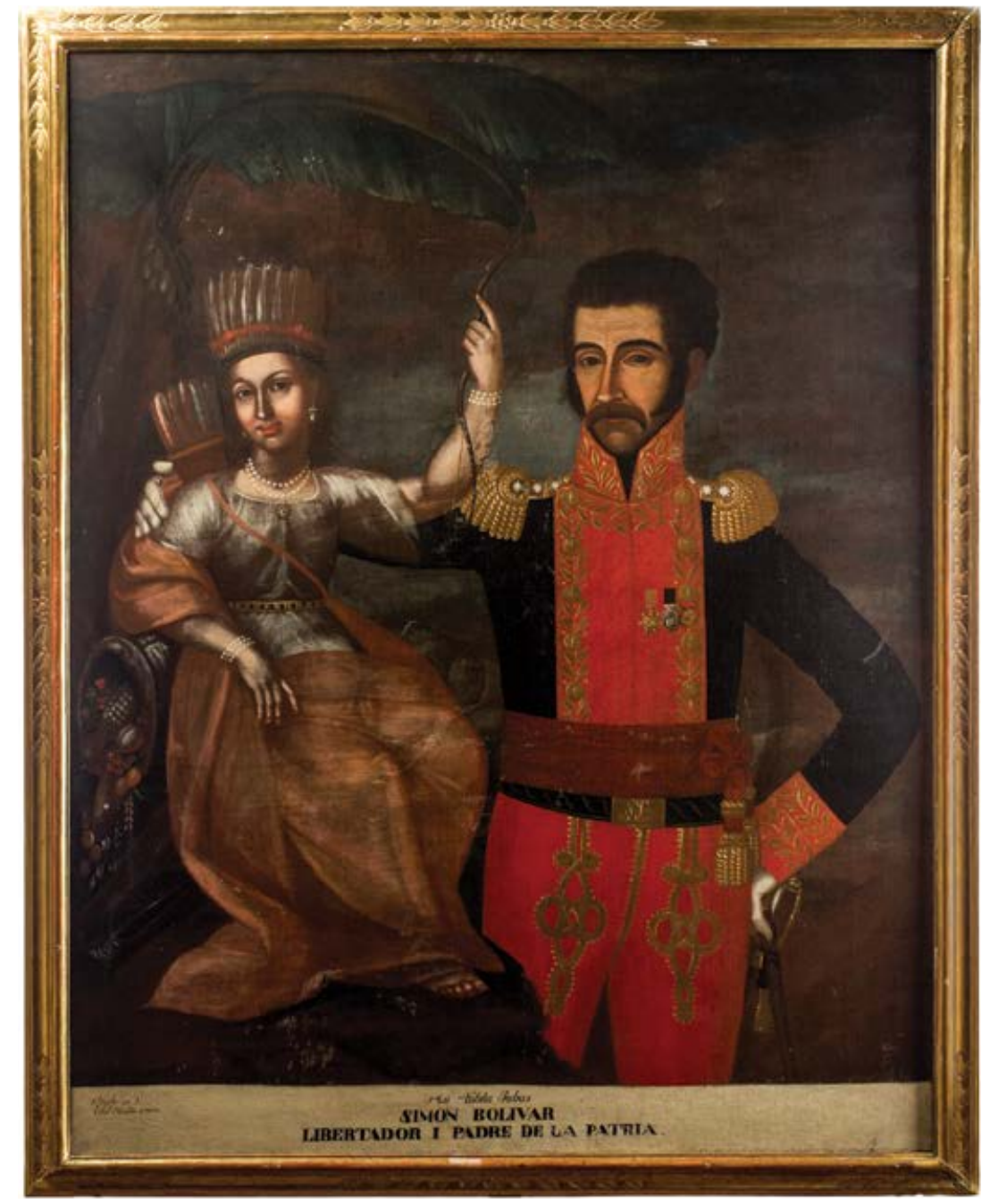

Figura 4. Pedro José de Figueroa, ca. 1819, Simón Bolivar, Libertador i Padre de la Patria (óleo sobre tela, $125 \times 97 \mathrm{~cm}$, Casa Museo Quinta de Bolívar, Bogotá) 
Una simbología semejante a la de Cartagena se usaba en el segundo centro del movimiento emancipador, en Santafé de Bogotá. Ya con el nombre tomado por esta región en 1811, se recurría al recuerdo del pasado y así se daba un sentido al nuevo Estado. La Junta Suprema había nombrado un comité electoral que debía elaborar una Constitución válida al menos para el área de la antigua provincia de Santafé. Este Colegio Electoral y Constituyente redactó en pocas semanas una Constitución que en el Título I, artículo $1^{\circ}$ dio al territorio de la antigua provincia de Santafé su supuesto nombre indígena original:

La Representación, libre y legítimamente constituida por elección y consentimiento del pueblo de esta provincia, que con su libertad ha recuperado, adopta y desea conservar su primitivo y original nombre de Cundinamarca, convencida y cierta de que el pueblo a quien representa ha reasumido su soberanía, recobrando la plenitud de sus derechos, [...] ordena y manda observar la presente. (Constitución de Cundinamarca, citada en Pombo y Guerra 1951, 126)

Si bien los criollos se equivocaron con el nombre, ya que el nombre Cundinamarca no era el nombre que le daban a su territorio sus propios habitantes, sino era la denominación por parte de los indígenas del sur, no cabe la menor duda de que ese nombre indígena fue escogido muy conscientemente para simbolizar la libertad recuperada y afirmar la justificación del movimiento independentista. Aun cuando no hay ninguna abierta exposición de intenciones, resulta natural llegar a esta conclusión, probada suficientemente por el análisis de los textos constitucionales y los documentos preparatorios. Además, este tipo de estrategias y procedimientos en tal fase de la formación del Estado y la nación son usuales y necesarios.

La evocación del pasado indígena con el fin de formar la identidad, justificarla y movilizar a la gente, así como la equiparación consciente de lo indiano con la libertad, se expresan con claridad en las monedas de Santafé de Bogotá, que Antonio Nariño mandó acuñar a partir de 1813. Con seguridad no resulta casual que estas monedas se hubieran concebido y puesto en circulación cuando, bajo la influencia de Antonio Nariño, Cundinamarca se había erigido en república con la nueva Constitución de abril de 1812; con ello se renunciaba al principio monárquico y a la ficción de un Fernando VII como rey de Cundinamarca y, por último, se declaró la separación absoluta de España el 16 de julio de 1813.

Así, en la sesión del 7 de agosto de 1813, pocos días después de la declaración de independencia absoluta, el Colegio Revisor y Electoral tomó en cuenta dos 
aspectos cuando decidió la circulación de monedas de plata con nuevos símbolos. En lugar del busto del rey español, que representaba la antigua dependencia, las monedas debían llevar en el anverso un busto femenino, una india coronada de plumas como símbolo de la libertad, con la leyenda libertad americana, y en el reverso una granada con la inscripción Nueva Granada Cundinamarca, así como indicaciones sobre el valor y el año de acuñación (Barriga y Villalba 1969: vol. 2, 143 y 144). Desde 1813 hasta 1816 se acuñaron monedas provinciales, reales y pesetas (diámetro de 25 milímetros), con la imagen de la indígena, y el cuartillo (diámetro de 11 a 12 milímetros) con el símbolo general de la libertad, el gorro frigio en el reverso y la granada en el anverso (Barriga y Villalba 1969: vol. 2, 155; figura 5).
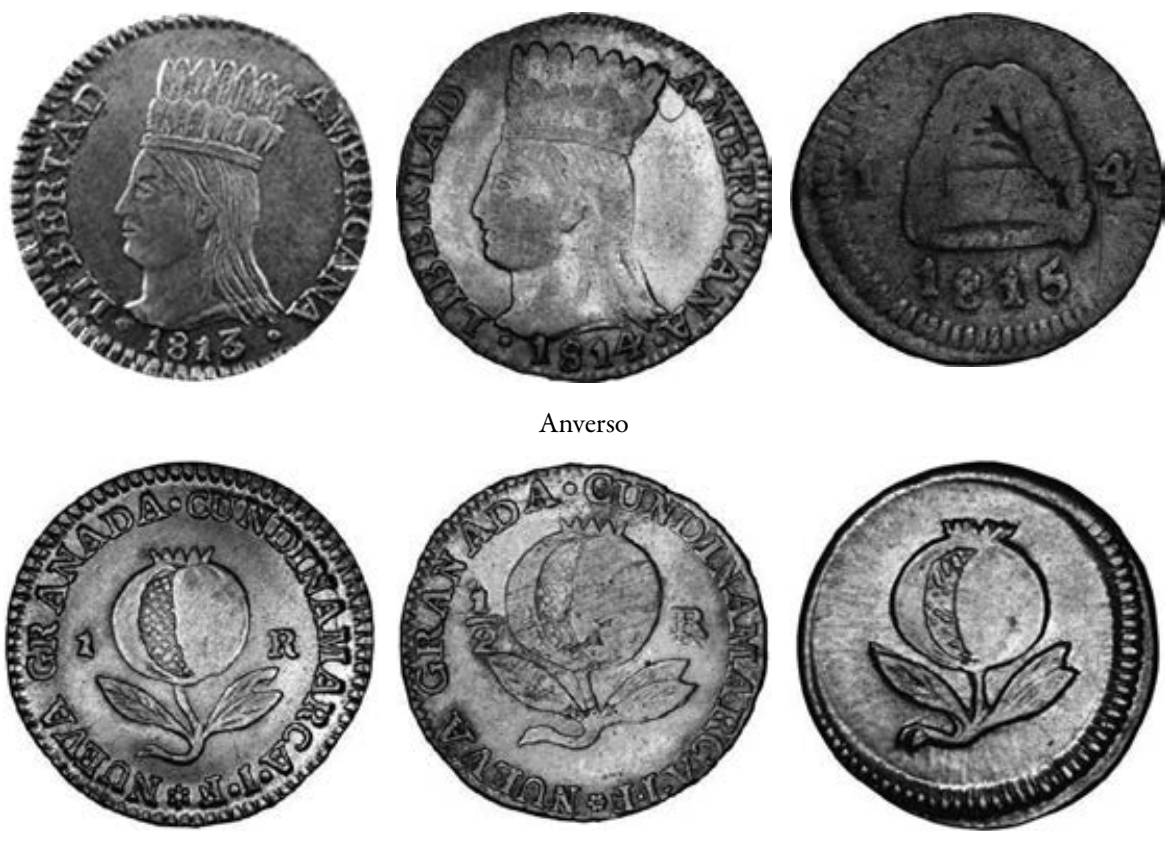

Reverso

Figura 5. Cuartillos de 1813 hasta 1815

Fuente: Barriga y Villalba (1969).

El uso no se limitó a la provincia de Cundinamarca, sino que fueron reconocidas como monedas nacionales en toda la Nueva Granada y también por parte del Congreso de las Provincias Unidas de la Nueva Granada el 16 de marzo de 1815. El símbolo de la india no contradecía de ninguna manera las metas de las Provincias Unidas, como lo muestran las frecuentes alusiones a lo "indiano" por 
parte de sus dirigentes políticos. En el entretanto, las Provincias Unidas, a las cuales Cundinamarca obedecía de manera más o menos forzada, decretaron simbolizar la libertad con una india en la Ley de 15 de julio de 1815 sobre el sistema monetario. El artículo 10 de esta ley, el cual subraya el acto soberano de la emisión monetaria, dispone - entre otras cosas - el aspecto de las piezas: “Todas ellas serán selladas en adelante en esta forma: el anverso llevará la figura de una amazona americana en pie, con la actitud y signos que le son característicos; la inscripción, independiente y libre [...]" (Posada 1924, 140).

Durante la restauración del dominio español en la Nueva Granada, entre 1816 y 1819, no se acuñaron monedas. El 21 de noviembre de 1819, después de la victoria en Boyacá sobre las tropas españolas, Bolívar dispuso una reacunación de la moneda de la India o moneda de la China, nombre con el cual se conocía la pieza monetaria de Cundinamarca, con el año cambiado pero con el mismo símbolo y sin el nombre adicional de Cundinamarca (Sociedad Bolivariana de Venezuela 1961: vol. 1, 172). Los bogotanos llamaban "chinas" a sus empleadas domésticas indígenas y así transmitían este nombre a la moneda con la imagen de la india.

El Congreso de Cúcuta decidió, el 29 de septiembre de 1821, estandarizar el sistema monetario de la recién formada Gran Colombia y sacar de circulación las monedas a ley reducida, lo mismo que las monedas de las provincias. No obstante, fueron acuñadas hasta 1828 y circularon en Bogotá, junto a las nuevas monedas oficiales, las monedas preferidas de la población, con la leyenda República de Colombia y los años antedatados (Barriga Villalba 1969: vol. 3, 11-14 y documento 12A, 295).

Así como no resultaba casual que se empezaran a acuñar monedas en cierto momento histórico, tampoco era obvia la elección del símbolo para ellas. Para ilustrar la libertad, también estaban a disposición símbolos no indígenas, como el gorro frigio de los revolucionarios jacobinos franceses, el cual efectivamente puede encontrarse — casi hasta la actualidad — en monedas y escudos de la Nueva Granada. Del uso continuado de la figura de la india se desprende que este símbolo adquirió una significación especial durante la fase de transición, al iniciarse la formación del Estado. Pero después de la construcción de la Gran Colombia, es decir, una vez lograda la libertad, la Asamblea Constituyente del Estado de Colombia, unión de la Nueva Granada y Venezuela, por medio de la Ley del 6 de octubre de 1821, remplazó en el escudo de armas y en las monedas oficiales la imagen de la india como personificación de la libertad, por un busto femenino en traje romano con una faja ceñida a la cabeza en que se ve grabada la palabra libertad (figura 6). 
Desde las primeras acuñaciones efectuadas en 1822, el busto romano se convirtió en el símbolo estándar de la libertad (Barriga Villalba 1969: vol. 3, 9-20).
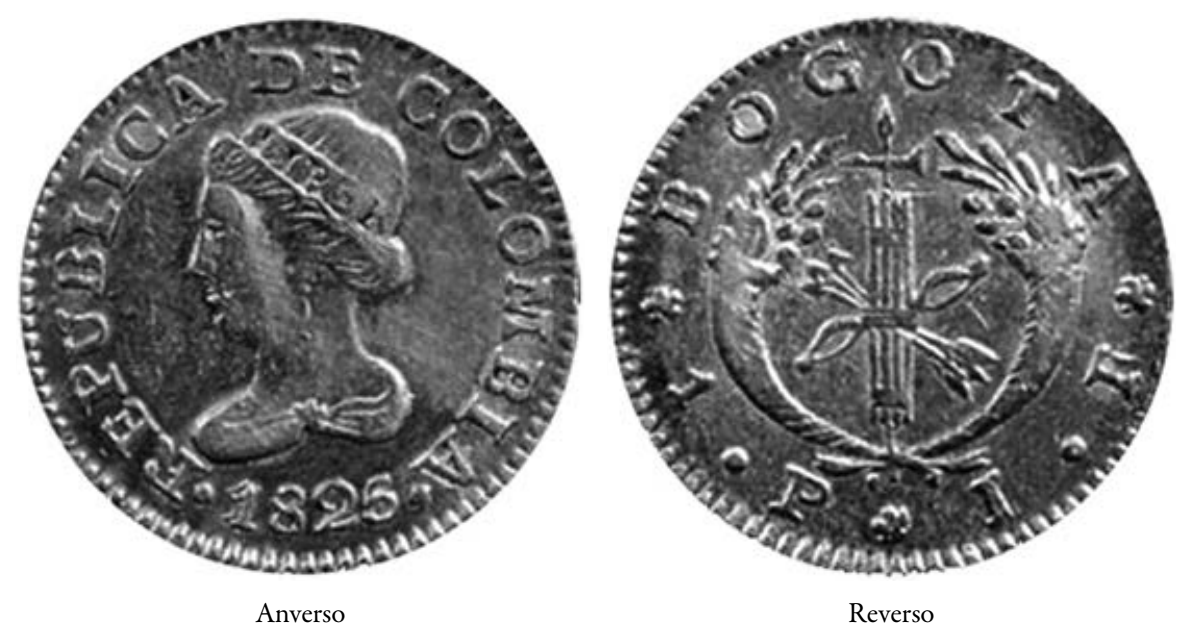

Figura 6. Moneda de 1825 con busto femenino en traje romano

Fuente: Barriga Villalba (1969).

Lo que podemos decir es que en 1821 la imagen de la india ya había cumplido su misión como símbolo justificador y movilizador. En un periodo en el que la Nueva Granada, tras la batalla de Boyacá, había sido liberada en su mayor parte; en que en Venezuela también se hacía patente la derrota de las tropas españolas y con ello la liberación completa; en que la fidelidad a los españoles, debida a las crueles represalias de los llamados pacificadores, disminuía y se hacía manifiesta la justificación de su lucha por la libertad y la necesidad de un cambio político ante el sangriento proceder de la Madre Patria; en un tiempo en el que el riesgo de la propia vida y la lucha común habían generado un sentimiento colectivo, en ese momento histórico ya no era necesaria la evocación de un pasado propio indiano y de una imagen que simbolizaba esclavitud o libertad.

El destino de los indios, la imagen de la india, lo "indiano" en general, representaban elementos ideales de un "pasado nacional", aun cuando construido, que indicaban una dominación extranjera y al mismo tiempo contenían la justificación, las pretensiones y las metas del movimiento emancipador. En efecto, la evocación del "pasado nacional" fue solo selectiva y distinguió conscientemente entre pasado útil y no útil. Útil fue la existencia de la población autóctona conquistada y oprimida por los españoles, con la cual cabía identificarse y solidarizarse debido al estatus de 
oprimidos. Tradiciones indígenas, como a propiedad común, no pasaban por útiles, porque parecían impedir los proyectos del futuro desarrollo nacional.

\section{El árbol de la libertad}

Cuán intensos fueron los esfuerzos de los dirigentes políticos de crear lealtad y confianza en la población frente al nuevo Estado y presentarlo como un orden de convivencia humana deseable y cuán conscientemente emplearon los símbolos correspondientes, lo demuestra la siembra o plantación de "árboles de la libertad" con sus respectivas festividades (véase Hernández de Alba 1989). Ellas tuvieron lugar en numerosos pueblos de la Nueva Granada, sobre todo en Cundinamarca desde 1813, cuando ya no era un secreto la intención de separarse en forma definitiva de España.

En sus pensamientos políticos, formulados por ejemplo en su Discurso para la apertura del Colegio Electoral de junio de 1813 (reproducido en Ocampo López 1974,574 y ss.), Antonio Nariño partió del supuesto de que la masa de la población no podía ser motivada con ideas sutiles, sino que debía ser orientada con actos sólidos y símbolos visibles. Parte de este proceso era la siembra del árbol de la libertad, la cual debía efectuarse públicamente y con la debida solemnidad. Por eso resulta comprensible que el 3 de marzo de 1813 el gobierno de Cundinamarca hiciera retirar un árbol de la libertad plantado en secreto en Santafé de Bogotá, subrayando así la falta de publicidad, y que ordenara su siembra oficial y solemne. En numerosos artículos, la prensa y bandas respectivas publicaron para este evento las necesarias aclaraciones sobre el sentido y significado.

Esta repetición de la plantación oficial y solemne tuvo lugar el 29 de abril de 1813 en la Plaza Mayor, después de que en la semana anterior Ignacio Herrera, confidente y partidario de Nariño, había mandado a plantar otro árbol de la libertad en Honda, a 160 kilómetros de distancia de Santafé de Bogotá. Ambos sucesos surtieron gran efecto público - las celebraciones en la capital, con participación de toda la población, duraron tres días - y fueron comentados detalladamente en la Gaceta Ministerial de Cundinamarca, publicación periódica oficial, número 112, el 20 de mayo de 1813. Estas festividades, que copiaban las fiestas revolucionarias en Francia (Cfr. Ehrard y Viallaneix 1977, cap. 2), fueron escritas también por el contemporáneo José María Caballero en su Diario (1974, 133 y ss.).

Otras plantaciones espectaculares se realizaron hasta 1816: en Santa Fe de Bogotá (19 de julio de 1813), Cali (24 de junio de 1814), Sogamoso (julio de 1815) y en Bogotá o Bacatá, un pueblo a la entrada de la capital ( 4 de febrero de 1816). 
Además, hubo otras siembras en algunas comunidades pequeñas de Cundinamarca, como resulta de acusatorios y causas judiciales contra sacerdotes de la época del terror bajo Pablo Morillo.

En tanto que el empleo de lo "indiano" sirvió para legitimar y fundamentar la pretensión de libertad de los neogranadinos, la plantación del árbol de la libertad sirvió en la Nueva Granada, como durante la revolución en Francia (Godechot 1968, 268 y 533), para aclarar los objetivos del nuevo Estado. De esta manera, los patriotas querían estimular la identificación de la población con la nueva entidad, caracterizada por aquellos valores que le habían faltado al sistema colonial español. En el proceso de formación del Estado de la Nueva Granada, proceso que al igual que sus análogos en otras latitudes americanas implicó la separación de un imperio colonial, las ideas políticas de libertad política y autodeterminación constituyeron los aspectos centrales de las declaraciones y el comportamiento. Por cierto, la pretendida libertad se manifestaba en las instituciones políticas y en las constituciones; la siembra del árbol de la libertad como metáfora de la aspiración a la libertad, sin embargo, era un símbolo visible adicional. Visible para los partidarios del movimiento emancipador, cuyo patriotismo tenía que ser estimulado y fortalecido contra todas las adversidades, probando las virtudes del nuevo Estado y la dignidad de su defensa; pero visible también para los partidarios del viejo orden todavía existentes, a quienes se les tenía que demostrar la firmeza de los patriotas.

En la fase del proceso de emancipación política de entonces, es decir, en la lucha todavía continuada contra el poder colonial, el árbol de la libertad representaba claramente un instrumento de movilización, que fuera de sus funciones como creador de lealtad y unidad interna, también estaba dirigido hacia el exterior, con el fin de fomentar la solidaridad y avivar el entusiasmo por la lucha contra el poder colonial. A favor de esta interpretación más amplia no solo habla la situación histórica; también las declaraciones de los contemporáneos, sobre el significado del árbol de la libertad, atestiguan esta doble función. Por una parte, se exponía que de ninguna manera cabía confundir libertad con libertinaje y anarquía, sino que, al contrario, significaba sujeción a las leyes y al gobierno elegido libremente por el pueblo. En efecto, libertad otorgaba la posibilidad a los ciudadanos de hacer todo cuanto no infringiera las leyes, ni perjudicase a otras personas. Por la otra, se hacía la diferencia entre el propio Estado de derecho y la arbitrariedad del poder colonial español; para entonces, los ciudadanos ya no dependían de la arbitrariedad o de la benevolencia de su opresor pasado, sus actos serían regulados por leyes. El acta de la plantación oficial del árbol de libertad en la plaza mayor de Bogotá del 29 de 
abril de 1813 expresa de manera muy concisa y exacta el significado del símbolo de la libertad:

El Gobierno [...] cree de su obligación advertiros que el signo que va a inaugurarse no demuestra la licencia y desenvoltura que malamente se le atribuye para cometer toda clase de crímenes, sin temor de que se corrijan [...]. Su significado verdadero es, que no dependéis del capricho y arbitrariedad de los tiranos, sino de la ley que indistintamente debe aplicarse al delincuente, y que entrasteis en el ejercicio de las altas funciones del hombre en sociedad. Lejos de nosotros el que mire cifrada en aquel símbolo la garantía de sus excesos! ¡iLejos el que atente contra la vida, la propiedad y seguridad del ciudadano ${ }_{j}$ Lejos el que no respete las providencias del Gobierno! (Gazeta Ministerial de Cundinamarca, citada en König 1994, 163 y ss.)

También por las reacciones de criollos leales a la Madre Patria España respecto de la siembra de árboles de libertad se puede deducir que el árbol de libertad fue un instrumento de gran valor para promover la identificación de la población con el nuevo Estado. Así, el sacerdote José Antonio de Torres y Peña en el quinto canto de su poema Santa Fe Cautiva de 1816 caracterizó el árbol de libertad como árbol funesto, árbol ominoso y detestable cuya función consistía “a borrar del Monarca la memoria” (Torres y Peña 1902).

Por cierto, no existen datos sobre el efecto real que tuvo el árbol de libertad en la toma de conciencia de la población, es decir, en su patriotismo. No obstante, dos incidentes prueban, al menos indirectamente, su eficiencia. Aún en 1816, cuando el ejército español bajo Pablo Morillo había tomado la ciudad de Cartagena y amenazaba la reconquista de toda la Nueva Granada, se plantó un árbol de libertad. Este evento ocurrió de manera significativa en el pueblo de Bogotá o Bacatá, la antigua sede del legítimo cacique de los chibchas, y la siembra fue realizada por una india coronada de plumas, como lo describió Caballero en su Diario:

Domingo 4. Se fue mucha gente a Bogotá (nombre antiguo de Funza) y plantaron en dicha parroquia el árbol de la libertad; llevaron un cerezo con tierra y una gorra colorada a mitad de la plaza, donde había un hoyo dispuesto. Iba una india con su corona dispuesta, con su corona de plumas. Salió una gran comitiva, con una música de la casa del cura, doctor Policarpo Jiménez, y muchos sacerdotes y caballeros y señoras. Dieron vuelta a toda la plaza, y en llegando al lugar del 
hoyo dijo la india: "Planto aquí el árbol que nuestros enemigos arrancaron con crueldad de este mismo lugar". [...] En seguida hizo el doctor Torres, cura de Facatativá, otra arenga, muy bien fundada, a la libertad. (Caballero 1971, 200)

No solo la fecha y las circunstancias históricas, sino también el destacado papel concedido a una india, permiten vislumbrar cuánta importancia atribuyeron los patriotas a un acto tal para movilizar y fortalecer la disposición de defensa, precisamente en los estratos bajos de la población.

\section{A manera de conclusión}

En vez de resumir este capítulo con muchas palabras, me permito terminar con dos ejemplos de imágenes que resaltan tanto el uso como la función de símbolos. Para aumentar el efecto de la alegoría de la india y del árbol de la libertad, los criollos combinaron los dos símbolos. Estos aparecieron en la misma ilustración: la india de la libertad recostada en el tronco de un árbol, como lo demuestra la portada de la publicación de la Constitución del Estado de Cartagena de Indias, de 1812, y el óleo de un anónimo, La india de la libertad, de 1819, hoy en el Museo del 20 de Julio. Esta india, al contrario de la mencionada arriba en el óleo de Figueroa, sí tiene tipo indígena y se encuentra semidesnuda (figuras 8 y 9 ).

Y que las imágenes son funciones de situaciones sociales, demuestra muy bien el uso o bien el no uso de la imagen de la india. A mediados del siglo XIX, cuando la soberanía del Estado estaba asegurada y cuando el poder político neogranadino tenía que legitimarse, más bien a través del rendimiento y la distribución de los recursos políticos y económicos, el elemento indígena no pareció ya tener fuerza. Se puede constatar que el símbolo de la india, sentada sobre un caimán, la alegoría de la libertad americana, desapareció, como lo comentó irónicamente un artículo de prensa, algunos años más tarde: "No nos ha quedado de él más que el caimán que devoró a la indiecilla” (König 1995, 471). 


\title{
CONSTITUCION
}

\author{
DEL ESTADO DE
}

\section{CARTAGENA DE INDIAS}

\author{
SANCIONADA
}

En 14. de funio del año de 1812. Segundo de su Independencia.

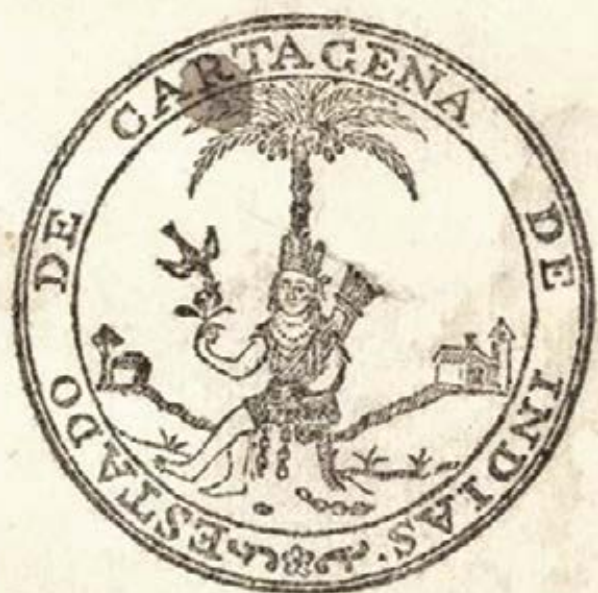

CARTAGENA DE INDIAS: EN LA IMPRENTS DEL CIUDADANO DIEGO ESPINOSA

Figura 7. Constitución del Estado de Cartagena 


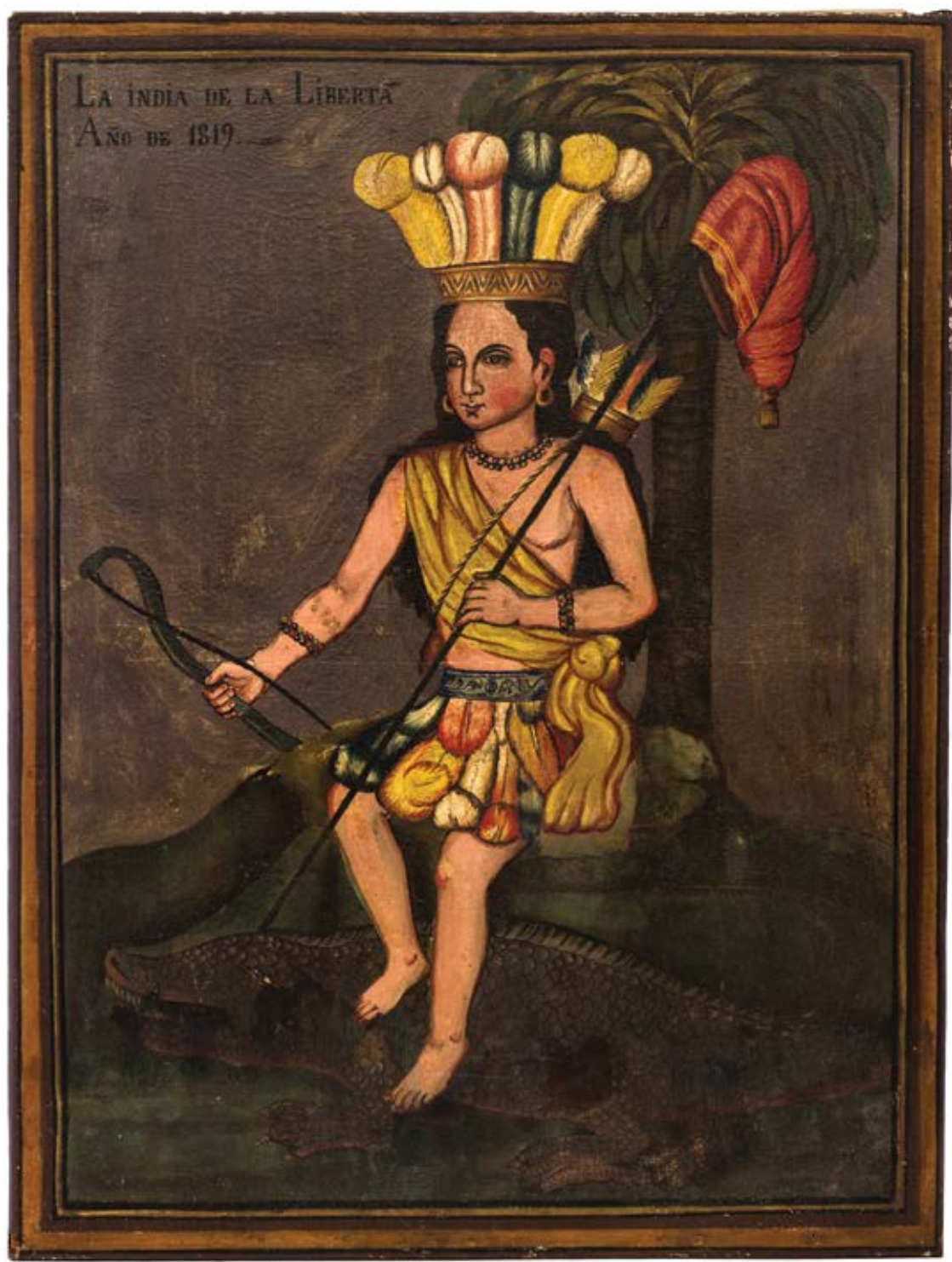

Figura 8. Anónimo, 1819, La India de la Libertad, 1812,

(óleo sobre tela, $82 \times 62 \mathrm{~cm}$, Museo de la Independencia, Bogotá) 


\section{Bibliografía}

Banco de la República. 1960. Proceso histórico del Veinte de Julio de 1810. Documentos. Bogotá: Banco de la República.

Barriga Villalba, Antonio M. 1969. Historia de la Casa de Moneda. 3 vols. Bogotá: Banco de la República.

Bergem, Wolfgang, Lothar Bluhm y Friedhelm Marx, editores. 1996. Metapher und Modell. Trier: WVT.

Berger, Peter L.y Thomas Luckmann. 1966. The Social Construction of Reality. Garden City: Doubleday.

Bergler, Reinhold. 1966. Psychologie Stereotyper Systeme. Bern \& Stuttgart: Huber.

Boulding, Kenneth E. 1969 [1956]. The Image. Ann Arbor: University of Michigan Press.

Burrows, Edwin G. y Michael Wallace. 1972. "The American Revolution: The Ideology and Psychology of National Liberation”. Perspectives in American History VI: 165-306.

Caballero, José María. 1974. Diario de la Independencia. Bogotá: Banco Popular.

Castro, Daniel, Beatriz González y Margarita González. 2004. El Libertador Simón Bolivar, creador de Repúblicas: iconografia revisada del Libertador. Bogotá: Museo Nacional de Colombia.

Cohen, Ted. 1979. "Metaphor and the Cultivation of Intimacy". En On Metaphor, editado por Sheldon Sacks, 1-10. Chicago: University of Chicago Press.

Collier, Simon. 1967. Ideas and Politics of Chilean Independence 1808-1833. Cambridge: Cambridge University Press.

Chicangana-Bayona, Yobenj Aucardo. 2010. "La india de la libertad: de las alegorías de América a las alegorías de la patria”. Argos 27, n. ${ }^{\circ}$ 53: 145-163.

Davidson Donald. 1978. "What Metaphors Mean". Critical Inquiry 5:31-47.

Deichmann, Carl. 2007. Symbolische Politik - Politische Symbole: Dimensionen Politischer Kultur. Schwalbach: Wochenschau.

Deutsch, Karl W. 1953. Nationalism and Social Communication. Cambridge: MIT Press.

Dieckmann, Walther. 1964. Information oder Überredung: Zum Wortgebrauch der politischen Werbung in Deutschland seit der Französischen Revolution. Marburg: Elwert.

Diers, Michael. 1997. Schlagbilder. Zur politischen Ikonographie der Gegenwart. Frankfurt/M.: Fischer. 
Ehrard, Jean y Paul Viallaneix, editores. 1977. Les Fêtes de la Révolution. Colloque de Clermont-Ferrand (juin 1974). Paris: Société des Études Robespierristes.

Fischer, Manfred S. 1979. "Komparatistische Imagologie. Für eine Erforschung national-imagotyper Systeme”. Zeitschrift für Sozialpsychologie 10: 30-44.

Gaceta de Colombia. 1812. 16 de julio.

García Canclini, Néstor. 1989. Culturas híbridas: estrategias para entrar y salir de la modernidad. México: Grijalba.

Gumprecht, Hans Ulrich. 1979. "Für eine phänomenologische Fundierung der sozialhistorischen Begriffsgeschichte". En Historische Semantik und Begriffsgeschichte, editado por Reinhart Koselleck, 75-101. Stuttgart: Klett-Cotta.

Haverkamp, Anselm, editor. 1983. Theorie der Metapher. Darmstadt: Wissenschaftliche Buchgesellschaft.

Hernández de Alba, Gonzalo. 1989. Los árboles de libertad: ecos de Francia en la Nueva Granada. Bogotá: Planeta.

Hoffmann, Johannes. 1960. Völkerbilder in Ost und West. Auswahlbibliographie. Dortmund: Rheinisch-Westfälische Auslandsgesellschaft.

Knefelkamp, Ulrich y Hans-Joachim König. 1988. Die Neuen Welten in alten Büchern. Bamberg: Staatsbibliothek.

Kohl, Karl-Heinz, editor. 1982. Mythen der Neuen Welt. Zur Entdeckungsgeschichte Lateinamerikas. Berlin: Frölich \& Kaufmann.

König, Hans-Joachim. 1991. "Vielfalt der Kulturen oder europäisches Muster? Amerika und Indios in frühen deutschen Schriftzeugnissen”. En Die Neue Welt im Bewusstsein der Italiener und Deutschen des 16. Jahrbunderts, editado por Adriano Prosperi y Wolfgang Reinhard, 175-213. Berlin: Duncker \& Humblot.

König, Hans-Joachim. 1994 [1988]. En el camino hacia la nación: nacionalismo en el proceso de formación del Estado y de la nación de la Nueva Granada, 1750-1856. Bogotá: Banco de la República.

König, Hans-Joachim. 1997. "El indigenismo criollo: ¿proyecto vital y político realizable, o instrumento político?". Historia Mexicana XLVI, n. ${ }^{\circ}$ 4: 745-767.

König, Hans-Joachim. 2000. "Nacionalismo y nación en la historia de Iberoamérica”. En Estado-nación, comunidad indígena, industria: tres debates al final del milenio, coordinado por Hans-Joachim König, Tristan Platt y Colin Lewis, 7-47. Leiden: AHILA.

König, Hans-Joachim. 2003. "Discursos de identidad, Estado nacional y ciudadanía en América Latina. Viejos problemas, nuevos enfoques y dimensiones”. En 
Entre discursos y prácticas: América Latina en el siglo XIX, editado por Eduardo Cavieres, 25-46. Valparaíso: Ed. Universitarias.

Lasswell, Harold D. 1949. “The Language of Power”. En Language of Politics, editado por Harold D. Lasswell et al., 3-19. New York: Stewart.

L'Amérique vue par l'Europe. 1976. Paris: Edition des Musées Nationaux.

Lowenthal Felstiner, Mary. 1983. "Family Metaphors: The Language of an Independence Revolution". Comparative Studies in Society and History 25: 154-180.

Martínez Delgado, Luis, editor. 1954. Noticia biográfica del prócer don Joaquín Camacho. Bogotá: Academia Colombiana de Historia.

McClung Fleming, E. 1965. “The American Image as Indian Princess 1765-1783”. Winterthur Portfolio II: 65-81.

Miller, Eugen F. 1979. “Metaphor and Political Knowledge”. En American Political Science Review 73, n. ${ }^{\circ}$ 1: 155-170.

Miranda, José. 1952. Las ideas y las instituciones politicas mexicanas. Ira parte 1512-1820. México: UNAM.

Múnera, Alfonso. 1998. El fracaso de la nación: región, clase y raza en el Caribe colombiano (1717-1821). Bogotá: Banco de la República.

Nariño, Antonio. 1966 [1811-1812]. La Bagatela. Bogotá: Vanegas (edición facsimilar).

Nariño, Antonio. 1974 [1813]. “Discurso sobre la apertura del Colegio Electoral”. En El proceso ideológico de la emancipación, 563-577. Tunja: Universidad Pedagógica y Tecnológica de Colombia.

Ortiz, Sergio E. editor. 1965. Colección de documentos para la historia de Colombia, $2^{\text {a }}$ serie. Bogotá: Kelly.

Ortony, Andrew, editor. 1979. Metaphor and Thought. Cambridge: Cambridge University Press.

Pérez Sarmiento, José Manuel, editor. 1939. Causas célebres a los precursores. 2 vols. Bogotá: Imprenta Nacional.

Pocock, J. G. A. 1971. Politics, Language and Time: Essays in Political Thought and History. New York: Atheneum.

Poeschel, Sabine. 1985. Studien zur Ikonographie der Erdteile in der Kunst des 16.-18. Jahrbunderts. München: Scaneg.

Pombo, Manuel Antonio y José Joaquín Guerra, editores. 1951. Constituciones de Colombia. 4 vols. Bogotá: Banco Popular.

Posada, Eduardo, editor. 1924. Congreso de las Provincias Unidas. Bogotá: Imprenta Nacional. 
Presidencia de la República. 1962. Documentos que hicieron historia. 5 vols. Caracas: Ediciones Conmemorativas del Sesquicentenario de la Independencia.

Ricœur, Paul. 1986 [1975]. Die lebendige Metapher. München: Fink.

Sapir J. David y J. Christopher Crocker, editor. 1977. The Social Use of Metaphor: Essays on the Anthropology of Rhetoric. Philadelphia: University of Pennsylvania Press.

Schochet, Gordon J. 1975. Patriarchalism in Political Thought: The Authoritarian Family and Political Speculation and Attitude, especially in Seventeenth-Century England. Oxford: Blackwell.

Schütz, Alfred y Thomas Luckmann. 1979. Strukturen der Lebenswelt. 2 vols. Frankfurt/M.: Suhrkamp.

Siebenmann, Gustav. 1992. "Methodisches zur Bildforschung”. En Das Bild Lateinamerikas im deutschen Sprachraum, editado por Gustav Siebenmann y HansJoachim König, 1-17. Tübingen: Max Niemayer.

Sociedad Bolivariana de Venezuela. 1961. Decretos del Libertador. 3 vols. Caracas: Imprenta Nacional.

Torres y Peña, José Antonio. 1902 [1818]. “Santa Fe Cautiva”. En La Patria Boba, editado por Eduardo Posada y Pedro María Ibáñez, 275-476. Bogotá: Imprenta Nacional.

Vargas, Pedro Fermín de. 1953. Pensamientospoliticos. Bogotá: Banco de la República. Walzer, Michael. 1967. “On the Role of Symbolism in Political Thought”. Political Science Quarterly 82: 191-204.

Weldon, T. D. 1953. The Vocabulary of Politics. Melbourne: Penguin Books.

Zashin, Elliot y Philip C. Chapman. 1974. "The Uses of Metaphor and Analogy: Toward a Renewal of Political Language". The Journal of Politics 36, n. 2 : 290-326. 